\title{
Indirect Effects of Pesticides on Natural Enemies
}

\author{
Raymond A. Cloyd
}

Additional information is available at the end of the chapter

http://dx.doi.org/10.5772/47244

\section{Introduction}

Pesticides including insecticides and miticides are primarily used to regulate arthropod (insect and mite) pest populations in agricultural and horticultural crop production systems. However, continual reliance on pesticides may eventually result in a number of potential ecological problems including resistance, secondary pest outbreaks, and/or target pest resurgence [1,2]. Therefore, implementation of alternative management strategies is justified in order to preserve existing pesticides and produce crops with minimal damage from arthropod pests. One option that has gained interest by producers is integrating pesticides with biological control agents or natural enemies including parasitoids and predators [3]. This is often referred to as 'compatibility,' which is the ability to integrate or combine natural enemies with pesticides so as to regulate arthropod pest populations without directly or indirectly affecting the life history parameters or population dynamics of natural enemies [2,4]. This may also refer to pesticides being effective against targeted arthropod pests but relatively non-harmful to natural enemies $[5,6]$.

Pesticides vary in their activity, which not only impacts how they kill arthropod pests but also how they may indirectly influence natural enemy populations. Pesticides may be classified as contact, stomach poison, systemic, and/or translaminar [7,8]. In addition, the application method-foliar vs. drench or granular-may determine the extent of any indirect effects on natural enemies [9] as well as the pesticide mode of action. The type of natural enemy - parasitoid or predator-may be influenced differently based on the factors mentioned above. Furthermore, the type of pesticide may substantially contribute to any indirect effects on natural enemies. For example, broad-spectrum, nerve toxin pesticides such as most of the older pesticides in the chemical classes, organophosphate (acephate and chlorpyrifos), carbamate (carbaryl and methiocarb), and pyrethroid (bifenthrin and cyfluthrin) may be both directly and indirectly more harmful to natural enemies than nonnerve toxin type pesticides (often referred to a "selective pesticides") including insect growth regulators (kinoprene and pyriproxyfen), insecticidal soaps (potassium salts of fatty 
acids), horticultural oils (petroleum or neem-based), selective feeding blockers (flonicamid and pymetrozine), and microbials (entomopathogenic fungi and bacteria, and other microorganisms) [10]. The non-nerve toxin pesticides are generally more specific or selective in regards to arthropod pest activity with broader modes of action than nerve toxin pesticides [3].

The effects of pesticides on natural enemies are typically associated with determining direct effects such as mortality or survival over a given time period (24 to 96 hours) [11]. While evaluations associated with the direct effects of pesticides on natural enemies are important, what are actually more relevant are the indirect or delayed effects of pesticides because this provides information on the long-term stability and overall success of a biological control program when attempting to integrate the use of pesticides with natural enemies [12-16].

Any indirect effects, which are sometimes referred to as sub-lethal, latent, or cumulative adverse effects may be associated with interfering with the physiology and behavior of natural enemies by inhibiting longevity, fecundity, reproduction (based on the number of progeny produced or eggs laid by females), development time, mobility, searching (foraging) and feeding behavior, predation and/or parasitism, prey consumption, emergence rates, and/or sex ratio [2,13,16,17-22].

\section{Indirect effects of pesticides on natural enemies}

In this book chapter, the term 'indirect' will be used for consistency. The indirect effects of pesticides on natural enemies (Table 1) have not been studied as extensively compared to direct effects, and those studies associated with indirect effects of pesticides have primarily involved evaluating fecundity and longevity [23-27].

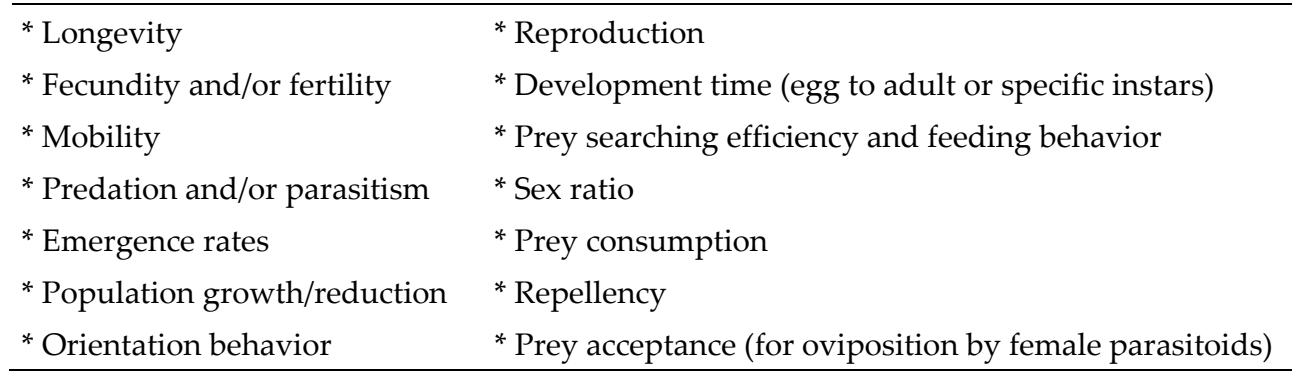

Modified from [2, 18].

Table 1. List of potential indirect effects of pesticides (insecticides, miticides, and fungicides) on the physiology and behavioral parameters of natural enemies (parasitoids and predators).

Although indirect effects may be more subtle or chronic compared to direct effects [14, 2829] any indirect effects may inhibit the ability of natural enemies to establish populations; suppress the capacity of natural enemies to utilize prey; impact parasitism (for parasitoids) or consumption (for predators) rates; decrease female reproduction; reduce prey 
availability; inhibit ability of natural enemies to recognize prey; influence the sex ratio (females: males); and reduce mobility, which could impact prey-finding [3, 27, 30-31]. In addition, more than one physiological and/or behavioral parameter may be indirectly affected after exposure to a pesticide. Furthermore, understanding the indirect effects of different concentrations of pesticides on fecundity, fertility, reproduction, adult and larva longevity, and prey consumption is important in successfully integrating natural enemies with pesticides and avoiding any indirect consequences on population dynamics $[16,32]$.

The important physiological and behavioral parameters presented above are responsible for allowing natural enemies to regulate arthropod pest populations. Some factors affiliated with natural enemies that may influence the indirect effects of pesticides include natural enemy age, type of natural enemy (parasitoid vs. predator), life stages (immature vs. adult) exposed to pesticides, and sex (male vs. female) [9,33]. In addition, the type of pesticide (nerve toxin vs. non-nerve toxin) as well as the pesticide application method (foliar vs. systemic) may have significant consequences and thus impact the extent of any indirect effects on natural enemies based on exposure (immediate vs. chronic). For example, foliar applications of pesticides, which in most cases, represents immediate exposure, that do not directly harm natural enemies may have indirect effects. Another indirect affect may be related to residues remaining after a foliar application, which could inhibit the emission of volatile cues from plants that are utilized by certain natural enemies to detect prey location (prey patches) from long distances within plant communities, thus impacting foraging behavior and searching efficiency [34-37]. Moreover, any residues remaining after application may indirectly affect parasitoids by inhibiting adult emergence [38].

Furthermore, natural enemies, particularly parasitoids, may be indirectly affected by feeding on contaminated honeydew excreted by phloem-feeding insect prey [39,40], which could significantly affect their performance. Certain pesticides (insecticides and fungicides) may also exhibit repellent activity [16,41-46] or alter host plant physiology $[13,47]$ thus indirectly affecting the ability of natural enemies to regulate existing arthropod pest populations [48].

This book chapter will now focus specifically on the indirect effects on natural enemies associated with different categories of pesticides including systemic insecticides, insect growth regulators, selective feeding blockers, microbials, miticides, and fungicides.

\section{Systemic insecticides}

Systemic insecticides, when applied as drenches or granules to the soil/growing medium, have been promoted to be relatively non-toxic to natural enemies due to lack of any direct exposure [49-51]. However, this may not be the case as systemic insecticides may exhibit indirect effects on natural enemies via several mechanisms including elimination of prey, contamination of floral parts by the active ingredient, consumption of the active ingredient while ingesting plant fluids, and contamination of prey ingesting either lethal or sub-lethal concentrations of the active ingredient [52-54]. Systemic insecticides, when applied to the soil or growing medium, may have minimal direct effects on aboveground natural enemies 
(both parasitoids and predators); however, they may indirectly influence natural enemies if mortality of prey populations is high $(>90 \%)$. This results in a reduction or potential elimination of available prey that serve as a food source for natural enemies [55-57], making it difficult for natural enemies to locate any remaining individuals. This would then lead to a decline in natural enemy populations either through starvation or dispersal thus suppressing establishment $[1,55,58-59]$. However, this effect is dependent on the foraging efficiency of the specific natural enemy. Furthermore, this may reduce the quantity or density of available prey or reduce their quality such that they are unacceptable as a food source for predators (both larvae and adults) or female parasitoids may not lay eggs. As such, reproduction, foraging behavior, fecundity, and longevity may all be indirectly affected [3].

The distribution of the systemic insecticide active ingredient into flower parts (petals and sepals) may indirectly impact natural enemies that feed on plant pollen or nectar as a nutritional food source including several species of predators such as minute pirate bug, Orius spp., which may feed on plants sometime during their life cycle [60-61] and certain parasitoids [62]. For example, adults of the parasitoid, Anagyrus pseudococci were indirectly affected after feeding on nectar of buckwheat (Fagopyrum esculentum) plants that had been treated with a soil application of a systemic insecticide [53]. Stapel et al. (2000) [11] found that foraging ability and longevity of the parasitioid, Microplitis croceipes was reduced after feeding on the extrafloral nectaries of cotton (Gossypium hirsutum) plants that had been treated with systemic insecticides. It was also noted that the application method (soil vs. foliar) and possibly timing of application (spatially and temporally) may influence any indirect effects on parasitoids that feed on flower pollen and nectar as a food source. In addition, foraging behavior may be altered depending on the exposure time and concentration of active ingredient present in floral portions of plants. As such, indirect effects associated with systemic insecticides may reduce the overall success of parasitoids in regulating arthropod pest populations under field conditions [11]. Translocation of systemic insecticides into flowers may indirectly affect natural enemies by altering foraging behavior as has been shown with the pink lady beetle, Colemegilla maculata, the green lacewing, Chrysoperla carnea, and the parasitoid, A. pseudococci [53,63-64]. Nevertheless, the ability of systemic insecticides, when applied to the soil or growing medium as a drench or granule, to move into floral parts may be contingent on water solubility, application rate, and plant type $[9,65]$.

In addition, the metabolites of certain systemic insecticides, which in general, may be more water soluble and toxic to arthropod pests, could be more concentrated in pollen and nectar than the actual active ingredient [66]. This might have a significant indirect effect on natural enemies. In fact, the metabolites associated with certain systemic insecticides have been implicated to indirectly affect natural enemies, primarily by contaminating flower pollen or extrafloral nectories as the active ingredient is translocated and distributed throughout plant parts [9]. Furthermore, any natural enemies feeding on prey that have fed upon plants and have ingested concentrations of the systemic insecticide active ingredient may be indirectly affected [67-68]. This is associated with prey contamination, which can lead to subtle and long-term indirect effects on parasitoids and/or predators [5,69]. 
Any indirect effects of systemic insecticides may also be associated with alterations in prey quality or induced changes in host plants [1,70-71], which may reduce the attractiveness of plants to parasitoids [13]; thus impacting the foraging behavior and searching efficiency of natural enemies $[13,72]$. The indirect effects of systemic insecticides, particularly on predators, may vary depending on feeding habits. For example, hemipteran predators, which may feed on plants as a supplemental food source, would likely be more indirectly affected than coccinellid predators that only feed on prey [2,5,73-76]. Furthermore, any odors associated with treated plants, may result in an avoidance response, which could inhibit the performance and thus effectiveness of natural enemies [11].

Exposure via both contact and oral-ingestion to systemic insecticides at variable concentrations indirectly affected both foraging ability and parasitization (parasitizing ability) of the parasitoid, Anagrus nilaparvatae [72]. Another indirect effect was a decrease in the ability of the parasitoid to perceive host-plant volatiles after being exposed to various concentrations of a systemic insecticide [72]. In addition, applications of certain systemic insecticides have been demonstrated to reduce reproduction of vedalia beetle, Rodolia cardinalis females and inhibit development from larvae to adult [67]. However, in a study in which nymphs and adults of the plant bug, Deraeocoris brevis were exposed to a systemic insecticide, there were no indirect effects on development or reproduction [72], which indicates variability associated with any indirect effects due to natural enemy type and species.

\section{Insect growth regulators}

Insect growth regulators are compounds that are active directly on the immature stages (larvae or nymphs) of certain insect pests, and there are three distinct categories of insect growth regulators: juvenile hormone mimics, chitin synthesis inhibitors, and ecdysone antagonists [78-79]. Insect growth regulators have been presumed to be compatible, with minimal indirect affects on natural enemies [80-83], and numerous studies have evaluated the indirect effects of insect growth regulators on natural enemies, both parasitoids and predators, under laboratory and field conditions. However, there is distinct variability regarding the indirect effects of insect growth regulators on natural enemies, which is primarily associated with natural enemy type (parasitoid or predator), kind of insect growth regulator, life stage evaluated, and timing of application (spatially and temporally).

\subsection{Pyriproxyfen}

The insect growth regulator pyriproxyfen, a juvenile hormone mimic [84-85] was demonstrated to have no indirect harmful effects on adult female oviposition and egg viability of the green lacewing, C. carnea [86]. Similarly, pyriproxyfen exhibited no indirect effects on development time, female longevity, and fertility of an Orius sp. after exposure under laboratory conditions [86]; however, these results may be inconclusive as control mortality was nearly $70 \%$. Pyriproxyfen did not negatively affect parasitism capacity of the 
parasitoid, Aphytis melinus and there were no indirect effects on the sex ratio of the progeny whereas female Coccophagus lycimnia failed to produce any progeny [87]. However, exposure to pyriproxyfen delayed development and decreased the parasitization rate of the parasitoid, Hyposoter didymator [88]. In addition, pyriproxyfen has been demonstrated to substantially alter the development time of Chrysoperla rufilabris immatures [89] whereas pyriproxyfen did not indirectly impact Delphastus catalinae female fecundity after adults had fed upon treated eggs of the sweet potato whitefly, Bemisia tabaci [83]. In another study, exposure of Podisus maculiventris fifth instars to pyriproxyfen did not result any indirect effects on reproduction [5]. The parasitoid species may influence any indirect effects as both Encarsia pergandiella and Encarsia transvena were not indirectly affected after exposure to pyriproxyfen whereas Encarsia formosa exhibited reduced emergence rates, increased development time, and decreased parasitization when exposed to different concentrations of pyriproxyfen [90]. This demonstrates that the parasitoid species, natural enemy type, and developmental life stage may influence the extent of any indirect effects of insect growth regulators.

\subsection{Kinoprene}

Another juvenile hormone mimic insect growth regulator, kinoprene [7], has been shown to be indirectly harmful to natural enemies by inhibiting adult emergence of the leafminer parasitoid, Opius dimidiatus [91] and the aphid parasitoid, Aphidius nigripes [92]. Although directly harmful to the parasitoid, Leptomastix dactylopii, kinoprene did not indirectly affect percent parasitoid emergence from citrus mealybug (Planococcus citri) mummies [93]. Nevertheless, kinoprene may inhibit adult emergence when applied to prey parasitized with larval or pupal stages of certain parasitoids [92].

\subsection{Fenoxycarb}

Fenoxycarb is a juvenile hormone analog [79,94-95] that has shown to be indirectly harmful to certain natural enemies. For example, different concentrations of fenoxycarb delayed the development time from pupae to adult of C. rufilabris [95], and significantly delayed development of third instar larvae but not first instar larvae. In addition, female reproduction was inhibited when second and third instars were initially exposed to fenoxycarb [96]. Grenier and Plantevin (1990) [97] demonstrated that fenoxycarb (at various concentrations) increased duration of larval development of the tachinid parasitoid, Pseudoperichaeta nigrolineata, and Bortolotti et al (2005) [98] observed a similar response (increased longevity) for the third instar larvae of C. carnea. In addition, exposure to fenoxycarb indirectly affected female longevity and fecundity of the predator, Micromus tasmaniae [99].

\subsection{Cyromazine}

Cyromazine is an insect growth regulator that disrupts molting by affecting cuticle sclerotization through increasing cuticle stiffness in insects [79], and has been shown to 
exhibit indirect effects on the reproduction of Phytoseiulus persimilis females [100] whereas no indirect effects, associated with adult emergence rates, were exhibited after the parasitoid, Chrysocharis parksi was exposed to cyromazine [101]. Furthermore, exposure to cyromazine did not indirectly affect longevity and reproduction of the leafminer parasitoids, Hemiptarsenus varicornis and Diglyphus isaea [57].

\subsection{Diflubenzuron}

Another insect growth regulator, diflubenzuron, which is a chitin synthesis inhibitor [79], has been shown, in general, to have minimal indirect impact on natural enemies-both parasitoids and predators-under laboratory and field conditions [10,102]. However, exposure to diflubenzuron decreased female longevity and reduced the parasitization rate of the endoparasitoid, Hyposoter didymator [88] and reproduction of the parasitoid, Eulophus pennicornis [103]. It was reported by [99] that M. tasmaniae, when exposed to diflubenzuron, resulted in indirect affects on reproduction, sex ratio (female bias), and longevity. In contrast, diflubenzuron exhibited no indirect effects on the reproduction of Podisus maculiventris adults [5]. Additionally, diflubenzuron displayed minimal indirect effects on the parasitoid, Macrocentrus ancylivorus [104]. Similar to other insect growth regulators, any indirect effects of diflubenzuron are likely associated with the natural enemy type, timing of application (spatially and temporally), and exposure time.

\subsection{Buprofezin}

Buprofezin, a chitin synthesis inhibitor $[79,105]$, has been shown to sterilize certain natural enemies [106], and reduce the number of progeny produced per female and alter sex ratios [87]. In addition, feeding on buprofezin-treated sweet potato whitefly (B. tabaci) eggs resulted in a decrease in female fertility and fecundity, and sterilized the males of the predatory coccinellid, Delphastus catalinae [83] indicating no compatibility with this insect growth regulator. However, buprofezin did not negatively affect development (nymph to adult) of the predatory bug, Orius tristicolor [107] or inhibit female reproduction of the predatory mite, P. persimilis [100]. In addition, buprofezin demonstrated no indirect affects on oviposition and foraging behavior of certain parasitoids including Eretmocerus sp., and Encarsia luteola [108]. Buprofezin, when applied at three different concentrations (100, 500, and 1,000 mg active ingredient per liter), did not indirectly affect egg viability and subsequent development of $C$. rufilabris. However, the higher rates (500 and 1,000 mg active ingredient per liter) when applied to first instars did prolong overall development to adult whereas second and third instars and pupae were not affected [109]. This indicates that the specific life stage exposed to insect growth regulators may vary in susceptibility with early instars tending to be more susceptible than later instars and adults to chitin synthesis inhibiting insect growth regulators [108,110-111]. In addition, the concentration in which natural enemies are exposed to may influence any indirect effects to these types of insect growth regulators. Furthermore, any indirect effects on natural enemies associated with buprofezin may be due to volatility of the compound as buprofezin is known to be volatile and display vapor activity against certain insect pests [112]. 


\subsection{Azadirachtin}

Azadirachtin is an ecdysone antagonist [78,113-114], which may exhibit variability regarding any indirect effects on natural enemies [115]. It was reported by [116], for example, that azadirachtin inhibits oviposition of the green lacewing, C. carnea and indirectly affected both fertility and fecundity [117]. In addition, exposure to azadirachtin decreased longevity and predation rates, and inhibited prey finding. Furthermore, the sex ratio was male biased ([88]. Three different formulations $(0.3 \%, 4.5 \%$, and $1.6 \%)$ of azadirachtin were reported to indirectly affect the fecundity of Macrolophus caliginosus females [118]. Reproduction of the aphid predator, Aphidoletes aphidimyza was not indirectly affected after exposure to azadirachtin [119], and azadirachtin did not indirectly affect the fecundity of the parasitoid, Aphidius colemani [120]; longevity and foraging ability of the parasitoids, Cotesia plutellae and Diadromus collaris and sex ratio of progeny [6]; nor reproduction of the predatory mite, Neoseiulus californicus [121]. Cloyd et al. (2009) [122] found, under laboratory conditions, that exposure to azadirachtin did not inhibit prey consumption (fungus gnat larvae) of rove beetle, Atheta coriaria adults. However, it was reported by [123] that first instar larvae of Harmonia axyridis, when exposed to azadirachtin, exhibited increased development time whereas there was no indirect affect on adult female fecundity.

Similar to buprofezin, this demonstrates that any indirect effects of insect growth regulators such as azadirachtin may be more prevalent on the early instars than the later instars of certain natural enemies [123]. Likewise, as also demonstrated by [124], development time of Coccinella septempunctata larvae was indirectly affected in a dose-dependent manner with fourth instar larvae more sensitive to azadirachtin than first instar larvae, which suggests that any indirect effects may be stage and age specific. As such, azadirachtin may be more indirectly harmful to nymphs and larval instars than adults under laboratory conditions whereas under semi-field or field conditions any indirect effects associated with these life stages are nullified [115].

\section{Selective feeding blockers}

Selective feeding blockers, which include flonicamid and pymetrozine, inhibit the feeding activity of piercing-sucking insects (aphids and whiteflies) after initial insertion of their stylets into plant tissues and interfere with neural regulation of fluid intake through the mouthparts resulting in starvation [125-130]. It was reported by [130] that both flonicamid and pymetrozine, did not negatively affect the development time, fertility, and parasitism of a variety of natural enemies including the hoverfly, Episyrphus balteatus; the carabid beetle, Bembidion lampros; the parasitoid, Aphidius rhopalosiphi; the ladybird beetle, Adalia bipunctata; and the rove beetle, Aleochara bilineata under laboratory conditions. In general, pymetrozine exhibited minimal indirect effects on the reproduction of $N$. californicus under laboratory conditions [121]. Cloyd and Dickinson (2006) [131] found that flonicamid did not indirectly affect parasitism, the sex ratio, and adult emergence of the parasitoid, L. dactylopii. Overall, minimal research has been conducted to determine the indirect effects of these types of 
pesticides on natural enemies; however, in general, they appear to be compatible, which is likely associated with their mode of action.

\section{Microbials}

Although entomopathogenic fungi and bacteria (Bacillus thuringiensis) are, in general, not indirectly harmful to natural enemies, this may vary depending on concentration, natural enemy type, life stage exposed, timing of application (spatially and temporally), and environmental conditions (temperature and relative humidity) [3,132]. Furthermore, any indirect effects may take longer to be expressed compared to other types of pesticides [133] as well as the fact that indirect effects may not be immediately associated with either the entomopathogenic fungi or bacteria, but may be due to altering the availability of the food source or killing prey before parasitoid immatures have completed development [134]. The bacterium, $B$. thuringiensis has been shown to have indirect effects on certain parasitoids although this is dependent on the formulation [135].

Natural enemies may ingest fungal conidia when grooming (cleaning themselves) or when feeding on contaminated hosts [10,104]; however, the extent of any indirect effects primarily depends on the concentration of spores present [136]. In addition, entomopathogenic fungi may indirectly affect certain natural enemies when feeding on prey that have been sprayed (contaminated prey). For example, larvae of the mealybug destroyer, Cryptolaemus montrouzieri were killed (50\% mortality) after consuming mealybugs that had been sprayed with Beauveria bassiana [133]. Moreover, exposure to $B$. bassiana reduced the fecundity of $N$. californicus females [121] whereas the fungus Cephalosporium lecanii exhibited no indirect effects on longevity of the leafminer parasitoid, Diglyphus begini [137]. In another study, conducted under laboratory conditions, [122] reported that exposure to Metarhizium anisopliae had no indirect effect on prey consumption (fungus gnat larvae) of rove beetle, A. coriaria adults. It was shown by [132] that exposure to Isaria (=Paecilomyces) fumosoroseus at a low relative humidity (55\%) resulted in no indirect effects on foraging behavior and longevity of the aphid parasitoid, Aphelinus asychis whereas both parameters were significantly reduced when exposed to a high $(\geq 95 \%)$ relative humidity, which could impact the ability of the parasitoid to regulate aphid populations. In addition, ovipositing females may avoid prey that are infected by entomopathogenic fungi [132].

The micro-organism spinosad has been demonstrated to be indirectly harmful to a variety of predatory insects including the green lacewing, C. carnea [138]; ladybird beetle, Hippodamia convergens; minute pirate bug, Orius laevigatus; big-eyed bug, Geocoris punctipes; and the damsel bug, Nabis sp. [139-140]. For example, it was determined by [141] that exposure to spinosad extended development time from first instar to adult and decreased fertility of Harmonia axyridis females. Nevertheless, exposure to spinosad did not inhibit foraging behavior and reproduction of $P$. persimilis females [142]. It has been shown by [143-144] that parasitoids may be indirectly affected by spinosad based on decreased reproduction and reduced longevity. However, exposure to spinosad did not indirectly affect the sex ratio of 
the parasitoids, Aphytis melinus and L. dactylopii, and there was no significant effect on reproduction and longevity of $L$. dactylopii females [87].

\section{Miticides}

Miticides, similar to other pesticides, may demonstrate variability in regards to any indirect effects on natural enemies depending on the type of miticide and predatory mite species [145]. It was reported by [145] that the miticide fenpyroximate did not negatively affect prey consumption of Neoseiulus (=Amblyseius) womersleyi on twospotted spider mite (Tetranychus urticae) eggs compared to the miticide pyridaben. However, both miticides indirectly affected reproduction of $N$. womersleyi and P. persimilis females. Egg viability of $P$. persimilis was not affected by either miticide but was for $N$. womersleyi. Furthermore, the population growth, based on reproduction and egg viability, of $N$. womersleyi was indirectly affected more so by pyridaben than fenpyroximate. Overall, fenpyroximate appeared to be more compatible with both predatory mite species. Similarly, [146] found that exposure to different concentrations of fenpyroximate did not indirectly affect female reproduction, immature development time, fecundity, and the sex ratio of progeny associated with $N$. womersleyi. Nevertheless, exposure to variable concentrations of fenpyroximate indirectly affected longevity and fecundity of P. plumifer females [147]. In another study, pyridaben inhibited reproduction of Galendromus occidentalis [148] whereas [149] reported no indirect effects associated with sex ratio and prey consumption of $P$. persimilis.

The miticides bifenazate, etoxazole, acequinocyl, chlorfenapyr, and fenbutatin oxide were shown to exhibit no indirect effects on the reproduction of $P$. persimilis females under laboratory conditions, and adult females that fed upon prey treated with the miticides were not indirectly affected based on sex ratio of progeny, prey consumption, and female reproduction [150]. This indicates that these miticides are in fact compatible with this predatory mite. In another study, [22] found that exposure to bifenazate did not reduce fecundity, longevity, or prey consumption of adult female P. persimilis or N. californicus. Moreover, exposure to bifenazate, etoxazole, acequinocyl, and chlorfenapyr under laboratory conditions did not indirectly affect fecundity or reproduction of N. womersleyi females. In addition, females that fed upon treated prey were in no way indirectly affected [151]. Overall, the miticide bifenazate appears to be compatible with a variety of predatory mite species.

\section{Fungicides}

Although, in general, fungicides may be considered less harmful to natural enemies than insecticides and miticides [18] it is still critical to determine any indirect effects and thus compatibility with natural enemies since fungicides are extensively used in agricultural and horticultural production systems and as such it is justifiable to evaluate their indirect effects on natural enemies. It may be that the fungicide type will determine compatibility with natural enemies as 'older' fungicides could be more indirectly harmful to natural enemies than 'newer' fungicides, which may be associated with the mode of action or any 
metabolites. Although similar to other pesticides, this may depend on the natural enemy type and species, timing of application (spatially and temporally), and life stage exposed. For example, mancozeb was shown to negatively affect fecundity and reproduction of the predatory mites, Amblyseius andersoni, G. occidentalis [42,152] and Euseius victoriensis [45] under laboratory and field conditions and benomyl indirectly inhibited reproduction of female Amblyseius fallacis [153] and G. occidentalis [148]. However, mancozeb did not indirectly affect longevity or reproduction of two leafminer parasitoids, Hemiptarsenus varicornis and Diglyphus isaea [57].

It was determined that the 'newer' fungicides, azoxystrobin and fosetyl-aluminum did not inhibit prey consumption (fungus gnat larvae) of rove beetle, A. coriaria adults under laboratory conditions [122]. Bostanian et al. (2009) [154] reported that none of the fungicides evaluated including myclobutanil, propiconazole, fenhexamid, and pyraclostrobin, had any indirect effects on the fecundity of the predatory mite, G. occidentalis, and the fungicides captan, mancozeb, and myclobutanil did not indirectly affect longevity and fecundity of $A$. fallacis females [155]. Exposure to the fungicides boscalid and kresoxim-methyl, which are relatively 'newer' fungicides did not indirectly affect fecundity of both E. victoriensis and G. occidentalis [45]; and [148] found that exposure to the fungicides myclobutanil and trifloxystrobin resulted in no indirect effects on fecundity of G. occidentalis.

\section{Additional factors associated with indirect effects of pesticides on natural enemies}

It is important to exercise caution when attempting to translate laboratory evaluations associated with indirect effects into predictions related to field performance of natural enemies [156-159]. Laboratory assays, for example, may fail to take into account the indirect effects of pesticides, which could underestimate their overall impact [18]. In addition, longterm evaluations conducted under field conditions provide more applicable information regarding pesticide-pest-natural enemy interactions [159] including how pesticides indirectly interfere with the synchrony between natural enemies and their prey [99]. Furthermore, field exposure is assumed to be less severe and more variable than laboratory exposure because of factors such as plant architecture (arrangement of leaves and branches), spray application coverage, pesticide degradation, and potential for recolonization [45]. In addition, the methodology used to evaluate indirect effects of pesticides on natural enemies may influence the results obtained [87].

Another potential issue to be considered is that any indirect effects of pesticides on natural enemies may not necessarily be affiliated with the active ingredient but due to inert ingredients in the commercial formulation [2,160-164]. It is possible that formulations such as emulsifiable concentrates (EC) and soluble powders (SP) may contain additives such as adjuvants, surfactants, solvents and/or carriers that are indirectly harmful to natural enemies $[45,165]$. Studies associated with how inert ingredients affect natural enemies are necessary in order to better understand the actual indirect impact of pesticides on natural enemies. 


\section{Summary}

This book chapter has demonstrated the feasibility of combining or integrating natural enemies with certain pesticides including systemic insecticides, insect growth regulators, selective feeding blockers, microbials, miticides, and fungicides. The information presented clearly indicates that combining pesticides with natural enemies is not straight-forward $[2,18]$ and that compatibility of natural enemies with pesticides depends on a range of factors including class of pesticide applied, natural enemy type (parasitoid or predator), natural enemy species, pesticide formulation, concentration in which natural enemies are exposed to, exposure time, timing of application (spatially and temporally), and developmental life stage (early vs. later instars) exposed to pesticide. In addition, more than one physiological or behavioral parameter (longevity, reproduction, fecundity, and/or searching efficiency) of a given natural enemy may be indirectly affected by pesticides. As such, there are three primary means by which natural enemies may be integrated with pesticides including pesticide selection (using non-nerve toxin or "selective" pesticides), spatial separation (applying pesticides to localized areas of infestation) of natural enemies and pesticides, and temporal discontinuity (applying pesticides when natural enemies are absent or when tolerable life stages are present) between natural enemies and pesticides $[2,132]$.

As [27] indicated, any indirect effects must be evaluated to determine if pesticides are compatible with natural enemies so as not to compromise long-term success of biological control programs. However, many pesticide manufacturers and suppliers make unsubstantiated claims that pesticides are safe to natural enemies without any references to testing methodology, which fails to take into consideration that results obtained associated with any indirect effects may vary depending on concentration, natural enemy species, pesticide exposure time, developmental life stage(s) evaluated, and the influence of residues and repellency [45]. Therefore, compatibility of natural enemies with pesticides is important if both these management strategies are to be integrated into programs designed to regulate arthropod pest populations and minimize plant damage.

\section{Author details}

Raymond A. Cloyd

Kansas State University, Department of Entomology, Manhattan, KS, USA

\section{References}

[1] Hardin MR, Benrey B, Coll M, Lamp WO, Roderick GK, Barbosa P. Arthropod pest Resurgence: an Overview of Potential Mechanisms. Crop Protection 1995;14 3-18.

[2] Ruberson JR., Nemoto H, Hirose Y. Pesticides and Conservation of Natural Enemies in Pest Management. In: Barbosa P. (ed.) Conservation Biological Control. Academic Press, San Diego, CA; 1998. p207-220. 
[3] Croft BA. Arthropod Biological Control Agents and Pesticides. John Wiley \& Sons, New York, NY; 1990.

[4] Cloyd R. Compatibility conflict: is the use of biological control agents with pesticides a viable management strategy? In: second international symposium on biological control of arthropods; Davos, Switzerland, 12-16 September 2005. USDA Forest Service Publication FHTET-2005-08 Vol. II; 2005.

[5] De Clercq P, De Cock A, Tirry L, Viñuela E, Degheele D. Toxicity of Diflubezuron and Pyriproxyfen to the Predatory Bug Podisus maculiventris. Entomologia Experimentalis et Applicata 1995;74 17-22.

[6] Charleston DS, Kfir R, Dicke M, Vet LEM. Impact of Botanical Pesticides Derived from Melia azedarach and Azadirachta indica on the Biology of Two Parasitoid Species of the Diamondback Moth. Biological Control 2005;33 131-142.

[7] Ware GW, Whitacre DM. The Pesticide Book. MeisterPro Information Resources, Willoughby, OH; 2005.

[8] Cloyd RA. Managing Insect and Mite Pests. In: Nau J. (ed.) Ball RedBook Vol. 2 (18 Edition). Ball Publishing, West Chicago, IL; 2011. p107-119.

[9] Cloyd RA., Bethke JA. Impact of Neonicotinoid Insecticides on Natural Enemies in Greenhouse and Interiorscape Environments. Pest Management Science 2011;67 3-9.

[10] Cloyd RA. Compatibility of Insecticides with Natural Enemies to Control Pests of Greenhouses and Conservatories. Journal of Entomological Science 2006;41 189-197.

[11] Stapel JO, Cortesero AM, Lewis WJ. Disruptive Sublethal Effects of Insecticides on Biological Control: Altered Foraging Ability and Life Span of a Parasitoid after Feeding on Extrafloral Nectar of Cotton Treated with Systemic Insecticides. Biological Control 2000;17 243-249.

[12] Jacobs RJ., Kouskolekas CA, Gross HR Jr. Responses of Trichogramma pretiosum (Hymenoptera: Trichogrammatidae) to Residues of Permethrin and Endosulfan. Environmental Entomology 1984;13 355-358.

[13] Elzen GW., O'Brien PJ, Powell JE. Toxic and Behavioral Effects of Selected Insecticides on the Heliothis Parasitoid Microplitis croceipes. Entomophaga 1989;34 87-94.

[14] Elzen GW. Sublethal Effects of Pesticides on Beneficial Parasitoids. In: Jepson PC. (ed.) Pesticides and Non-Target Invertebrates. Intercept, Wimborne, UK; 1990. p129-150.

[15] Roger C, Vincent C, Coderre D. Mortality and Predation Efficiency of Coleomegilla lengi Timb. (Col., Coccinellidae) Following Application of Neem Extracts (Azadirachta indica A. Juss., Meliaceae). Journal of Applied Entomology 1995;119 439-443.

[16] Desneux N, Decourtye A, Delpuech J-M. The Sublethal Effects of Pesticides on Beneficial Arthropods. Annual Review of Entomology 2007;52 81-106.

[17] Moriarty F. The Sublethal Effects of Synthetic Insecticides on Insects. Biological Reviews 1969;44 321-357.

[18] Wright DJ, Verkerk RHJ. Integration of Chemical and Biological Control Systems for Arthropods: Evaluation in a Multitrophic Context. Pesticide Science 1995;44 207-218. 
[19] Jones WA, Ciomperlik MA, Wolfenbarger DA. Lethal and Sublethal Effects of Insecticides on two Parasitoids Attacking Bemisia argentifolii (Homoptera: Aleyrodidae). Biological Control 1998;11 70-76.

[20] Stark JD, Banks JE. Population-Level Effects of Pesticides and Other Toxicants on Arthropods. Annual Review of Entomology 2003;48 505-519.

[21] Croft BA, Brown AWA. Responses of Arthropod Natural Enemies to Insecticides. Annual Review of Entomology 1975;20 285-335.

[22] Ochiai N, Mizuno M, Mimori N, Miyake T, Dekeyser M, Canlas LJ, Takeda M. Toxicity of Bifenazate and its Principal Active Metabolite, Diazene, to Tetranychus urticae and Panonychus citri and Their Relative Toxicity to the Predaceous Mites, Phytoseiulus persimilis and Neoseiulus californicus. Experimental and Applied Acarology 2007;43 181197.

[23] Grosch DS. Reproductive Performance of a Braconid After Heptachlor Poisoning. Journal of Economic Entomology 1970;63 1348-1349.

[24] Grosch DS. Reproductive Performance of Bracon hebetor After Sublethal Doses of Carbaryl. Journal of Economic Entomology 1975;68 659-662.

[25] O' Brien PJ, Elzen GW, Vinson SB. Toxicity of Azinophos Methyl and Chlordimeform to Parasitoid Bracon mellitor (Hymenoptera: Braconidae): Lethal and Sublethal Effects. Environmental Entomology 1985;14 891-894.

[26] Hsieh CY, Allen WW. Effects of Insecticides on Emergence, Survival, Longevity, and Fecundity of the Parasitoid Diaeretiella rapae (Hymenoptera: Aphididae) from Mummified Myzus persicae (Homoptera: Aphididae). Journal of Economic Entomology 1986;79 1599-1602.

[27] Rosenheim JA, Hoy MA. Sublethal Effects of Pesticides on the Parasitoid Aphytis melinus (Hymenoptera: Aphelinidae). Journal of Economic Entomology 1988;81 476-483.

[28] Borgemeister C, Poehling HM, Dinter A, Holler C. Effects of Insecticides on LifeHistory Parameters of the Aphid Parasitoid Aphidius rhopalosiphi (Hym, Aphidiidae). Entomophaga 1993;38 245-255.

[29] Haseeb M, Liu TX, Jones WA. Effects of Selected Insecticides on Cotesia plutellae, Endoparasitoid of Plutella xylostella. BioControl 2004;49 33-46.

[30] van de Veire M, Tirry L. Side Effects of Pesticides on Four Species of Beneficials Used in IPM in Glasshouse Vegetable Crops: 'Worst Case' Laboratory Tests. Bulletin of the Organization of International Biological Control 2003;26 41-50.

[31] Grafton-Cardwell EE, Lee JE, Stewart JR Olsen KD. Role of Two Insect Growth Regulators in Integrated Pest Management of Citrus Scales. Journal of Economic Entomology 2006; 99 733-744.

[32] Sáenz-de-Cabzón Irigaray FJ, Zalom FG, Thompson PB. Residual Toxicity of Acaricides to Galendromus occidentalis and Phytoseiulus persimilis Reproductive Potential. Biological Control 2007;40 153-159.

[33] Bartlett BR. Integration of Chemical and Biological Control. In: DeBach P. (ed.) Biological Control of Insect Pests and Weeds. Chapman and Hall, New York, NY; 1964. p489-511. 
[34] Dicke M, Vet LEM. Plant-Carnivore Interactions: Evolutionary and Ecological Consequences for Plant, Herbivore and Carnivore. In: Oliff $\mathrm{H}$, Brown VK, Drent RH.(eds.) Herbivores: Between Plant and Predators. Blackwell Science, Oxford, UK; 1999. p483-520.

[35] Morgan DJW, Hare JD. Volatile Cues Used by the Parasitoid, Aphytis melinus, for Host Location: California Red Scale Revisited. Entomologia Experimentalis et Applicata 2003; 88 235-245.

[36] Gohole LS, Overholt WA, Khan ZR, Vet LEM. Role of Volatiles Emitted by Host and Non-Host plants in the Foraging Behaviour of Dentichasmias busseolae, a Pupal Parasitoid of the Spotted Stemborer Chilo partellus. Entomologia Experimentalis et Applicata 2003;107 1-9.

[37] Teodoro AV, Pallini A, Oliveira C. Sub-Lethal Effects of Fenbutatin Oxide on Prey Location by the Predatory Mite Iphiseiodes zuluagai (Acari: Phytoseiidae). Experimental and Applied Acarology 2009;47 293-299.

[38] Rill SM, Grafton-Cardwell EE, Morse JG. Effects of Two Insect Growth Regulators and a Neonicotinoid on Various Life Stages of Aphytis melinus (Hymenoptera: Aphelinidae). BioControl 2008;53 579-587.

[39] Longley M, Jepson PC. Effects of Honeydew and Insecticide Residues on the Distribution of Foraging Aphid Parasitoids Under Glasshouse and Field Conditions. Entomologia Experimentalis et Applicata 1996;81 189-198.

[40] Wang HY, Yang Y, Su JY, Shen JL, Gao CF, Zhu YC. Assessment of the Impact of Insecticides on Anagrus nilaparvatae (Pang et Wang) (Hymenoptera: Mymanidae), an Egg Parasitoid of the Rice Planthopper, Nilaparvata lugens (Hemiptera: Delphacidae). Crop Protection 2008;27 514-522.

[41] Bartlett BR. The Repellent Effects of Some Pesticides to Hymenopterous Parasites and Coccinellid Predators. Journal of Economic Entomology 1965;58 294-296.

[42] Ioriatti C, Pasqualini E, Toniolli A. Effects of the Fungicides Mancozeb and Dithianon on Mortality and Reproduction of the Predatory Mite Amblyseius andersoni. Experimental and Applied Acarology 1992;15 109-116.

[43] Blümel S, Pertl C, Bakker FM. Comparative Trials on the Effects of Two Fungicides on a Predatory Mite in the Laboratory and in the Field. Entomologia Experimentalis et Applicata 2000; 97 321-330.

[44] Hoddle MS, Van Driesche RG, Lyon SM, Sanderson JP. Compatibility of Insect Growth Regulators with Eretmocerus eremicus (Hymenoptera: Aphelinidae) for Whitefly (Homoptera: Aleyrodidae) Control on Poinsettias. Biological Control 2001;20 122-131.

[45] Bernard MB, Horne PA, Hoffmann AA. Developing an Ecotoxicological Testing Standard for Predatory Mites in Australia: Acute and Sublethal Effects of Fungicides on Euseius victoriensis and Galendromus occidentalis (Acarina: Phytoseiidae). Journal of Economic Entomology 2004; 97(3) 891-899.

[46] Garcia P. Sublethal Effects of Pyrethroids on Insect Parasitoids: What We Need Further Know. In: Stoytcheva M. (ed.) Pesticides: Formulations, Effects, Fate. Rijeka: Intech; 2011. p477-494. 
[47] Tran DH, Takagi M, Takasu K. Effects of Selective Insecticides on Host Searching and Oviposition Behavior of Neochrysocharis formosa (Westwood) (Hymenoptera: Eulophidae), a Larval Parasitoid of the American Serpentine Leafminer. Applied Entomology and Zoology 2004; 39 435-441.

[48] Umoru PA, Powell W, Clark SJ. 1996. Effect of Pirimicarb on the Foraging Behaviour of Diaeretiella rapae (Hymenoptera: Braconidae) on Host-Free and Infested Oilseed Rape Plants. Bulletin of Entomological Research 1996;86 193-201.

[49] Ripper WE, Greenslade RM, Hartley GS. Selective Insecticides and Biological Control. Journal of Economic Entomology 1951;44 448-459.

[50] McClanahan RJ. Food-Chain Toxicity of Systemic Acaricides to Predaceous Mites. Nature 1967;215 1001.

[51] Mizell RF, Sconyers MC. Toxicity of Imidacloprid to Selected Arthropod Predators in the Laboratory. Florida Entomologist 1992;75 277-280.

[52] Tillman PG, Mullinix BG. Comparison of Susceptibility of Pest Euschistus servus and Predator Podisus maculiventris (Heteroptera: Pentatomidae) to Selected Insecticides. Journal of Economic Entomology 2004;97 800-806.

[53] Krischik VA, Landmark AL, Heimpel GE. Soil-Applied Imidacloprid is Translocated to Nectar and Kills Nectar-Feeding Anagyrus pseudococci (Girault) (Hymenoptera: Encyrtidae). Environmental Entomology 2007;36 1238-1245.

[54] Szczepaniec A, Creary SF, Laskowski KL, Nyrop JP, Raupp MJ. Neonicotinoid insecticide imidacloprid causes outbreaks of spider mites on elm trees in urban landscapes. PLoS ONE 2011; 6(5): e20018. doi:10.1371/journal.pone.0020018 (accessed 13 February 2012).

[55] Radcliffe EB. Population responses of green peach aphid in Minnesota on potatoes treated with various insecticides. In: Proceedings of the North Central Branch of the Entomological Society of America 1972;27 103-105.

[56] Kiritani K. Pest Management of Rice. Annual Review of Entomology 1979;24 279-312.

[57] Bjorksten TA, Robinson M. Juvenile and Sublethal Effects of Selected Pesticides on the Leafminer Parasitoids Hemiptarsenus varicornis and Diglyphus isaea (Hymenoptera: Eulophidae) from Australia. Journal of Economic Entomology 2005;98 1831-1838.

[58] Flanders SE. Environmental Resistance to the Establishment of Parasitic Hymenoptera. Annals of the Entomological Society of America 1940;33 245-253.

[59] Ripper WE. Biological Control as a Supplement to Chemical Control of Insects. Nature 1944;153 448-551.

[60] Kiman ZB, Yeargan KV. Development and Reproduction of the Predator Orius insidiosus (Hemiptera: Anthocoridae) Reared on the Diets of Selected Plant Material and Arthropod Prey. Annals of the Entomological Society of America 1985;78 464-467.

[61] Hagen KS. Ecosystem Analysis: Plant Cultivars (HPR), Entomophagous Species and Food Supplements. In: Boethel DJ., Eikenbary RD (eds.) Interactions of Plant Resistance and Parasitoids and Predators of Insects. John Wiley \& Sons, Inc., New York, NY; 1986. p151-197. 
[62] Stapel JO, Cortesero AM, De Moraes CM, Tumlinson JH, Lewis WJ. Effects of Extrafloral Nectar, Honeydew, and Sucrose on Searching Behavior and Efficiency of Microplitis croceipes (Hymenoptera: Braconidae) in Cotton. Environmental Entomology 1997;26 617-623.

[63] Smith SF, Krischik VA. Effects of Systemic Imidacloprid on Coleomegilla maculata (Coleoptera: Coccinellidae). Environmental Entomology 1999;28 1189-1195.

[64] Rogers MA, Krischik VA, Martin LA. Effects of Soil application of Imidacloprid on Survival of Adult Green Lacewing, Chrysoperla carnea (Neuroptera: Chrysopidae), used for Biological Control in Greenhouses. Biological Control 2007;42 172-177.

[65] Cloyd RA, Sadof CS. Flower Quality, Flower Number, and Western Flower Thrips Density on Transvaal Daisy Treated with Granular Insecticides. HortTechnology 1998;8 567-570.

[66] Sur R, Stork A. Uptake, Translocation and Metabolism of Imidacloprid in Plants. Bulletin of Insectology 2003;56 35-40.

[67] Grafton-Cardwell EE, Gu P. Conserving Vedalia Beetle, Rodolia cardinalis (Mulsant) (Coleoptera: Coccinellidae), in Citrus a Continuing Challenge as New Insecticides Gain Registration. Journal of Economic Entomology 2003;96 1388-1398.

[68] Walker MK, Stufkens MAW, Wallace AR. Indirect Non-Target Effects of Insecticides on Tasmanian Brown Lacewing (Micromus tasmaniae) from Feeding on Lettuce Aphid (Nasonovia ribisnigri). Biological Control 2007;43 31-40.

[69] Singh SR, Walters KFA, Port GR, Northing P. Consumption Rates of Predatory Activity of Adult and Fourth Instar Larvae of the Seven Spot Ladybird, Coccinella septempunctata (L.), Following Contact with Dimethoate Residue and Contaminated Prey in Laboratory Arenas. Biological Control 2004;30 127-133.

[70] Smith HS. The utilization of entomophagous insects in the control of citrus pests. In: Transcripts from the $4^{\text {th }}$ International Congress of Entomology II, Ithaca, NY; 1929. p191-198.

[71] Hussey NW, Huffaker CB. Spider mites. In: Delucchi VL. (ed.) Studies in Biological Control. Cambridge University Press, Cambridge, UK; 1976.

[72] Liu F, Bao SW, Song Y, Lu HY, Xu JX. Effects of Imidacloprid on the Orientation Behavior and Parasitizing Capacity of Anagrus nilaparvatae, an Egg Parasitoid of Nilaparvata lugens. BioControl 2010;5 473-483.

[73] Ridgway RL, Lindgren PD, Cowan CB Jr, Davis JW. Populations of Arthropod Predators and Heliothis spp. After Applications of Systemic Insecticides to Cotton. Journal of Economic Entomology 1967;60 1012-1016.

[74] Stoner A. Plant Feeding by a Predaceous Insect Geocoris punctipes. Journal of Economic Entomology 1970;63 1911-1915.

[75] Morrison DE, Bradley JR Jr, van Duyn JW. Populations of Corn Earworm and Associated Predators after Application of Certain Soil-Applied Pesticides to Soybean. Journal of EconomicEntomology 1979;72 97-100.

[76] Salas-Aguilar J, Ehler LE. Feeding Habits of Orius tristicolor. Annals of the Entomological Society of America 1977;70 60-62. 
[77] Kim DS, Brooks DJ, Riedl H. Lethal and Sublethal Effects of Abamectin, Spinosad, Methoxyfenozide and Acetamiprid on the Predaceous Plant Bug Deraeocoris brevis in the Laboratory. BioControl 2006;51 465-484.

[78] Stenersen J. Chemical Pesticides: Mode of Action and Toxicology. CRC Press, Boca Raton, FL; 2004.

[79] Yu SJ. The Toxicology and Biochemistry of Insecticides. CRC Press, Taylor \& Francis Group, Boca Raton, FL; 2008.

[80] Staal GB. Insect Growth Regulators with Juvenile Hormone Activity. Annual Review of Entomology 1975;20 417-460.

[81] Ables JR, Jones SL, Bee MJ. Effect of Diflubenzuron on Beneficial Arthropods Associated with Cotton. Southwestern Entomologist 1977;2 66-72.

[82] Keever DW, Bradley JR Jr, Ganyard MC. Effects of Diflubenzuron (Dimilin) on Selected Beneficial Arthropods on Cotton Fields. Environmental Entomology 1977;6 732-736.

[83] Liu T-X, Stansly PA. Lethal and Sublethal Effects of Two Insect Growth Regulators on Adult Delphastus catalinae (Coleoptera: Coccinellidae), a Predator of Whiteflies (Homoptera: Aleyrodidae). Biological Control 2004;30 298-305.

[84] Koehler PG, Patterson RJ. Incorporation of Pyriproxyfen in German Cockroach (Dictyoptera: Blattelidae) Management Program. Journal of Economic Entomology 1991; 84 917-921.

[85] Ishaaya I, Barazani A, Kontsedalov S, Horowitz AR. Insecticides with Novel Modes of Action: Mechanism, Selectivity and Cross-Resistance. Entomological Research 2007;37 148-152.

[86] Nagai K. Effects of Juvenile Hormone Mimic Material, 4-phenoxyphenyl (RS)-2-(2pyridyloxy) Propyl Ether, on Thrips palmi Karny (Thysanoptera: Thripidae) and its Predator Orius sp. (Hemiptera: Anthocoridae). Applied Entomology and Zoology 1990; 25 199-204.

[87] Suma P, Zappalá L, Mazzeo G, Siscaro G. Lethal and Sub-Lethal Effects of Insecticides on Natural Enemies of Citrus Scale Pests. BioControl 2009;54 651-661.

[88] Schneider MI, Smagghe G, Pineda S, Viñuela E. Action of Insect Growth Regulator Insecticides and Spinosad on Life History Parameters and Absorption in Third-Instar Larvae of the Endoparasitoid Hyposoter didymator. Biological Control 2004;31 189-198.

[89] Chen TY, Liu TX. Susceptibility of Immature Stages of Chrysoperla rufilabris (Neurop., Chrysopidae) to Pyriproxyfen, a Juvenile Hormone. Journal of Applied Entomology 2002;125 125-129.

[90] Liu T-X, Stansly PA. Effects of Pyriproxyfen on Three Species of Encarsia (Hymenoptera: Aphelinidae), endoparasitoids of Bemisia argentifolii (Homoptera: Aleyrodidae). Journal of Economic Entomology 1997;90(2) 404-411.

[91] Lemma KM, Poe SL. Juvenile Hormone Analogues: Effects of ZR-777 on Liromyza sativae and its Endoparasite. Florida Entomologist 1978;61 67-68.

[92] McNeil J. Juvenile Hormone Analogs: Detrimental Effects on the Development of an Endoparasitoid. Science 1975;189 640-642. 
[93] Rothwangl KB, Cloyd RA, Wiedenmann RN. 2004. Effects of Insect Growth Regulators on Citrus Mealybug Parasitoid Leptomastix dactylopii (Hymenoptera: Encyrtidae). Journal of Economic Entomology 2004;97 1239-1244.

[94] Grenier S, Grenier AM. Fenoxycarb, a Fairly New Insect Growth Regulator: a Review of its Effects on Insects. Annals of Applied Biology 1993;122 369-403.

[95] Liu T-X, Chen T-Y. Effects of the Insect Growth Regulator Fenoxycarb on Immature Chrysoperla rufilabris (Neuroptera: Chrysopidae). Florida Entomologist 2001;84 628-633.

[96] Celli G, Bortolotti L, Nanni C, Porrini C, Brenna GS. Effects of the IGR Fenoxycarb on Eggs and Larvae of Chrysoperla carnea (Neuroptera: Chrysopidae). Laboratory Test. In: Haskell PT, McEwen PK. (eds.) New Studies in Ecotoxicology. The Welsh Pest Management in Forum, Cardiff, UK; 1997. p15-18.

[97] Grenier S, Plantevin G. Development Modifications of the Parasitoid Pseudoperichaeta nigrolineata (Dipt., Tachinidae) by Fenoxycarb, an Insect Growth Regulator, Applied onto its Host Ostrinia nubilalis (Lep., Pyralidae). Journal of Applied Entomology 1990;110 462-470.

[98] Bortolotti L, Micciarelli Sbrenna A, and Sbrenna G. Action of Fenoxycarb on Metamorphosis and Cocoon Spinning in Chrysoperla carnea (Neuroptera: Chrysopidae): Identification of the JHA-Sensitive Period. European Journal of Entomology 2005; 102 27-32.

[99] Rumpf S, Frampton C, Dietrich DR. Effects of Conventional Insecticides and Insect Growth Regulators on Fecundity and Other Life-Table Parameters of Micromus tasmaniae (Neuroptera: Hemerobiidae). Journal of Economic Entomology 1998;91 34-40.

[100] Blümel S, Stolz M. 1993. Investigations on the Effect of Insect Growth Regulators and Inhibitors on the Predatory Mite Phytoseiulus persimilis A. H. with Particular Emphasis on Cyromazine. Journal of Plant Disease and Plant Protection 1993;100 150-154.

[101] Parrella MP, Christie GD, Robb KL. Compatibility of Insect Growth Regulators and Chrysocharis parksi (Hymenoptera: Eulophidae) for the Control of Liriomyza trifolii (Diptera: Agromyzidae). Journal of Economic Entomology 1983;76 949-951.

[102] Gordon R, Cornect M. 1986. Toxicity of the Insect Growth Regulator Diflubenzuron to the Rove Beetle Aleochara bilineata, a Parasitoid and Predator of the Cabbage Maggot Delia radicum. Entomologia Experimentalis et Applicata 1986;42 179-185.

[103] Butaye L, Degheele D. Benzoylphenyl Ureas Effect on Growth and Development of Eulophus pennicornis (Hymenoptera: Eulophidae), a Larval Ectoparasite of the Cabbage Moth (Lepidoptera: Noctuidae). Journal of Economic Entomology 1995;88(3) 600-605.

[104] Broadbent AB, Pree DJ. Effects of Diflubenzuron and BAY SIR 8514 on Beneficial Insects Associated with Peach. Environmental Entomology 1984;13 133-136.

[105] Ishaaya I, Mendelson Z, Melamed-Madjar V. 1988. Effect of Buprofezin on Embryogenesis and Progeny Formation of Sweet Potato Whitefly (Homoptera: Aleyrodidae). Journal of Economic Entomology 1988;81 781-784.

[106] Hattingh V, Tate B. Effects of Field-Weathered Residues of Insect Growth Regulators on some Coccinellidae (Coleoptera) of Economic Importance as Biological Controls. Bulletin of Entomological Research 1995;85 489-493. 
[107] James DG. 2004. Effect of Buprofezin on Survival of Immature Stages of Harmonia axyridis, Stethorus punctum picipes (Coleoptera: Coccinellidae), Orius tristicolor (Hemiptera: Anthocoridae), and Geocoris spp. (Hemiptera: Geocoridae). Journal of Economic Entomology 2004;97 900-904.

[108] Gerling D, Sinaip. Buprofezin Effects on Two Parasitoid Species of Whitefly (Homoptera: Aleyrodidae). Journal of Economic Entomology 1994;87 842-846.

[109] Liu T-X, Chen T-Y. 2000. Effects of the Chitin Synthesis Inhibitor Buprofezin on Survival and Development of Immatures of Chrysoperla rufilabris (Neuroptera: Chrysopidae). Journal of Economic Entomology 2000;93 234-239.

[110] Retnakaran A., and Wright JE. Control of Insect Pests with Benzoylphenyl Ureas. In: Wright JE., Retnakaran A. (eds.) Chitin and Benzoylphenyl Ureas. Dr. W. Junk Publishers, Netherlands; 1987. p205-282.

[111] Darvas B, Polgar LA. Novel Type Insecticides: Specificity and Effects on Non-Target Organisms. In: Ishaaya I., Degheele D. (eds.) Insecticides with Novel Modes of Action. Springer, Berlin, Germany; 1998. p188-259.

[112] De Cock A, Ishaaya I, Degheele D, Veierov D. Vapor Toxicity and Concentration Dependent Persistence of Buprofezin Applied to Cotton Foliage for Controlling the Sweet Potato Whitefly (Homoptera: Aleyrodidae). Journal of Economic Entomology 1990;83 1254-1260.

[113] Ascher KRS. Non-Conventional Insecticidal Effects of Pesticides Available from the Neem Tree, Azadirachta indica. Archives of Insect Biochemistry and Physiology 1993;22 433-449.

[114] Mordue AJ, Simmonds MSJ, Ley SV, Blaney WM, Mordue W, Nasiruddin M, and Nisbet AJ. Actions of Azadirachtin, a Plant Allelochemical Against Insects. Pesticide Science 1998;54 277-284.

[115] Schmutterer H. Side-Effects of Neem (Azadirachta indica) Products on Insect Pathogens and Natural Enemies of Spider Mites and Insects. Journal of Applied Entomology 197;121 121-128.

[116] Medina P, Smagghe G, Budia F, Tirry L. Vinuela E. Toxicity and Absorption of Azadirachtin, Diflubenzuron, Pyriproxyfen, and Tebufenozide after Topical Application in Predatory Larvae of Chrysoperla carnea (Neuroptera: Chrysopidae). Environmental Entomology 2003;32 196-203.

[117] Medina P, Budia F, Del Estal P, Viñela E. Influence of Azadirachtin, a Botanical Insecticide, on Chrysoperla carnea (Stephens) Reproduction: Toxicity and Ultrastructural Approach. Journal of Economic Entomology 2004;97 43-50.

[118] Tedeschi R, Alma A, Tavella L. Side-Effects of Three Neem (Azadirachta indica A. Juss) Products on the Predator Macrolophus caliginosus Wagner (Het., Miridae). Journal of Applied Entomology 2001;125 397-402.

[119] Spollen KM, Isman MB. Acute and Sublethal Effects of a Neem Insecticide on the Commercial Biological Control Agents Phytoseiulus persimilis and Amblyseius cucumeris (Acari: Phytoseiidae) and Aphidoletes aphidimyza (Diptera: Cecidomyiidae). Journal of Economic Entomology 1996;89 1379-1386. 
[120] Stara J, Ourednickova J, Kocourek F. Laboratory Evaluation of the Side Effects of Insecticides on Aphidius colemani (Hymenoptera: Aphidiidae), Aphidoletes aphidimyza (Diptera: Cecidomyiidae), and Neoseiulus cucumeris (Acari: Phytoseidae). Journal of Pesticide Science 2011;84 25-31.

[121] Castagnoli M, Liguori M, Simoni S, Duso C. Toxicity of some Insecticides to Tetranychus urticae, Neoseiulus californicus and Tydeus californicus. BioControl 2005;50 611-622.

[122] Cloyd RA, Timmons NR, Goebel JM, Kemp KE. Effect of Pesticides on Adult Rove Beetle Atheta coriaria (Coleoptera: Staphylinidae) Survival in Growing Medium. Journal of Economic Entomology 2009;102 1750-1758.

[123] Kraiss H, Cullen EM. Insect Growth Regulator Effects of Azadirachtin and Neem Oil on Survivorship, Development and Fecundity of Aphis glycines (Homoptera: Aphididae) and its Predator, Harmonia axyrides (Coleoptera: Coccinellidae). Pest Management Science 2008;64 660-668.

[124] Banken JA, Stark JD. 1997. Stage and Age Influence on the Susceptibility of Coccinella septempunctata (Coleoptera: Coccinellidae) after Direct Exposure to Neemix, a Neem Insecticide. Journal of Economic Entomology 1997;90 1102-1105.

[125] Kayser H, Kaufmann L, Schurmann F, Harrewijn P. Pymetrozine (CGA 215'944): A Novel Compound for Aphid and Whitefly Control. An Overview of its Mode of Action. In: Proceedings of the 1994 Brighton Crop Protection Conference-Pests and Diseases 1994;2 737-742.

[126] Harrewijn P, Kayser H. 1997. Pymetrozine, a Fast-Acting and Selective Inhibitor of Aphid Feeding. In-Situ Studies with Electronic Monitoring of Feeding Behavior. Pesticide Science 1997;49 130-140.

[127] Fuog D, Fergusson SJ, Fluckiger C. Pymetrozine: A Novel Insecticide Affecting Aphids and Whiteflies. In: Ishaaya I., and Degheele D (eds.) Insecticides with Novel Modes of Action. Springer-Verlag, New York, NY; 1998. p40-49.

[128] Hollingworth RM, Treacy MF. 2006. Classification and Properties of Commercial Insecticides and Acaricides. In: All JN., Treacy MF. (eds.) Use and Management of Insecticides, Acaricides, and Transgenic Crops. The American Phytopathological Society, St. Paul, MN; 2006. p36-67.

[129] Morita M, Ueda T, Yoneda T, Koyanagi T, Haga T. Flonicamid, a Novel Insecticide with a Rapid Inhibitory Effect on Aphid Feeding. Pest Management Science 2007;63 969-973.

[130] Jansen JP, Defrance T, Warnier AM. Side Effects of Flonicamid and Pymetrozine on Five Aphid Natural Enemy Species. BioControl 2011;56 759-770.

[131] Cloyd RA, Dickinson A. Effect of Insecticides on Mealybug Destroyer (Coleoptera: Coccinellidae) and Parasitoid Leptomastix dactylopii (Hymenoptera: Encyrtidae), Natural Enemies of Citrus Mealybug (Homoptera: Pseudococcidae). Journal of Economic Entomology 2006;99 1596-1604.

[132] Lacey LA, Mesquita ALM, Mercadier G, Debire R, Kazmer DJ, Lecant F. Acute and Sublethal Activity of the Entomopathogenic Fungus Paecilomyces fumosoroseus 
(Deuteromycotina: Hyphomycetes) on Adult Aphelinus asychis (Hymenoptera: Aphelinidae). Environmental Entomology 1977;26 1452-1460.

[133] Kiselek EV. 1975. The Effect of Biopreparations on Insect Enemies. Zashchita Rastenii Moskva 175;12 23.

[134] Marchal-Segault D. 1975. Susceptibility of the Hymenopterous Braconids Apanteles glomeratus and Phanerotoma glavitestacea to the Spore-Crystal Complex of Bacillus thuringiensis Berliner. Annales de Zoologic Ecologie Animale 1975;6 521-528.

[135] Thoms EM, Watson TF. Effect of Dipel (Bacillus thuringiensis) on the Survival of Immature and Adult Hyposoter exiguae (Hymenoptera: Ichneumonidae). Journal of Invertebrate Pathology 1986;47 178-183.

[136] James RR, Lighthart B. Susceptibility of the Convergent Lady Beetle (Coleoptera: Coccinellidae) to Four Entomogenous Fungi. Environmental Entomology 1994;23: 190192.

[137] Bethke JA, Parrella MP. Compatibility of the Aphid Fungus Cephalosporium lecanii with the Leafminer Parasite, Diglyphus beginii (Hymenoptera: Eulophidae). Pan-Pacific Entomologist 1989;65 385-390.

[138] Medina P, Budia F, Tirry L, Smagghe G, Vinuela E. 2001. Compatibility of Spinosad, Tebufenozide and Azadirachtin with Eggs and Pupae of the Predator Chrysoperla carnea (Stephens) Under Laboratory Conditions. Biocontrol Science and Technology 2001;11 597-610.

[139] Thompson GD, Dutton R, Sparks TC. Spinosad-a Case Study: an Example from Natural Products Discovery Programme. Pest Management Science 200;56 696-702.

[140] Copping LG. The Biopesticide Manual. BCPC Publishing, Bracknell, UK; 2001.

[141] Galvan TL, Koch RL, Hutchison WD. Effects of Spinosad and Indoxacarb on Survival, Development, and Reproduction of the Multicolored Asian Lady Beetle (Coleoptera: Coccinellidae). Biological Control 2005;34 108-114.

[142] Holt KM, Opit GP, Nechols JR, Margolies DC. Testing for Non-Target Effects of Spinosad on Twospotted Spider Mites and their Predator Phytoseiulus persimilis under Greenhouse Conditions. Experimental and Applied Acarology 2006;38 141-149.

[143] Miles M, Dutton R. Spinosad-a Naturally Derived Insect Control Agent with Potential for Use in Integrated Pest Management Systems in Greenhouses. In: Proceedings of the BCPC Conference-Pests and Diseases, November 13-16, 2000. British Crop Protection Council, Farnham, Surrey, UK. Brighton, UK; 2000. p339-344.

[144] Williams T, Valle J, Viñuela E. Is the Naturally Derived Insecticide Spinosad Compatible with Insect Natural Enemies? Biocontrol Science and Technolnology 2003;13 459-475.

[145] Park J-J, Kim M, Lee J-H, Shin K-I, Lee S-E, Kim J-G, Cho K. Sublethal Effects of Fenpyroximate and Pyridaben on Two Predatory Mite Species, Neoseiulus womersleyi and Phytoseiulus persimilis (Acari, Phytoseiidae). Experimental and Applied Acarology 2011;54 243-259.

[146] Kim SS, Paik CH. Comparative Toxicity of Fenpyroximate to the Predatory Mite, Amblyseius womersleyi Schicha and the Kanzawa Spider Mite, Tetranychus kanzawai 
Kishida (Acarina: Phytoseiidae, Tetranychidae). Applied Entomology and Zoology 1996;31 369-377.

[147] Hamedi N, Fathipour Y, Saber M. Sublethal Effects of Fenpyroximate on Life Table Parameters of the Predatory Mite Phytoseius plumifer. BioControl 2010;55 271-278.

[148] Alston DG, Thomson, SV. Effects of Fungicide Residues on the Survival, Fecundity, and Predation of the Mites Tetranychus urticae (Acari: Tetranychidae) and Galendromus occidentalis (Acari: Phytoseiidae). Journal of Economic Entomology 2004;97 950-956.

[149] Ahn K, Lee SY, Lee KY, Lee YS, Kim GH. Selective Toxicity of Pesticides to the Predatory Mite, Phytoseiulus persimilis and Control Effects of the Two-Spotted Spider Mite, Tetranychus urticae by Predatory Mite and Pesticide Mixture on Rose. Korean Journal of Applied Entomology 2004;43 71-79.

[150] Kim SS, Yoo SS. Comparative Toxicity of some Acaricides to the Predatory Mite, Phytoseiulus persimilis and the Twospotted Spider Mite, Tetranychus urticae. BioControl 2002;47 563-573.

[151] Kim SS, Seo SG. Relative Toxicity of some Acaricides to the Predatory Mite, Amblyseius womersleyi and the Twospotted Spider Mite, Tetranychus urticae (Acari: Phytoseiidae, Tetranychidae). Applied Entomology and Zoology 2001;36 509-514.

[152] Angeli G, Ioriatti C. Susceptibility of Two Strains of Amblyseius andersoni Chant. (Acari: Phytoseiidae) to Dithiocarbamate Fungicides. Experimental and Applied Acarology 1994;18 669-679.

[153] Nakashima MJ, Croft BA. Toxicity of Benomyl to the Life Stages of Amblyseius fallacis. Journal of Economic Entomology 1974;67 675-677.

[154] Bostanian NJ, Thistlewood HMA, Hardman JM, Racette G. Toxicity of Six Novel Fungicides and Sulphur to Galendromus occidentalis (Acari: Phytoseiidae). Experimental and Applied Acarology 2009;47 63-69.

[155] Bostanian NJ, Thistlewood H, Racette G. Effects of Five Fungicides used in Quebec Apple Orchards on Amblyseius fallacis (Garman) (Phytoseiidae: Acari). Journal of Horticultural Science and Biotechnology 1998;73 527-530.

[156] Hoy MA, Cave FE. Laboratory Evaluation of Avermectin as a Selective Acaricide for use with Metaseiulus occidentalis (Nesbitt) (Acarina: Phytoseiidae). Applied Entomology and Zoology 1985;39 401-409.

[157] Kogan M. Ecological Theory and Integrated Pest Management Practice. John Wiley \& Sons, New York, NY; 1986.

[158] Stark JD, Jeppson PC, Mayer DF. Limitations to use of Topical Toxicity Data for Predictions of Pesticide Side Effects in the Field. Journal of Economic Entomology 1995;88 1081-1088.

[159] Villanuéva-Jimenez JA, Hoy MA. Toxicity of Pesticides to the Citrus Leaf Miner and its Parasitoid Ageniaspis citricola Evaluated to Assess their Suitability for an IPM Program in Citrus Nurseries. BioControl 1998;43 357-388.

[160] Dahl GH, Lowell JR. Microencapsulated Pesticides and their Effects on Non-Target Insects. In: Scher HB. (ed.) Advances in Pesticide Formulation Technology. American Chemistry Society, Washington, D. C. USA; 1984. p141-150. 
[161] Stevens PJG. Organosilicone Surfactants as Adjuvants for Agrochemicals. Pesticide Science 1993;38 103-122.

[162] Imai T, Tsuchiya S, Fujimori T. Aphicidal Effects of Silwet L-77, Organosilicone Nonionic Surfactant. Applied Entomology and Zoology 1995;30 380-382.

[163] Wood BW, Tedders WL, Taylor J. Control of Pecan Aphids with an Organosilicone Surfactant. HortScience 1997;32 1074-1076.

[164] Cowles RS, Cowles EA, McDermott AM, Ramoutar D. “Inert" Formulation Ingredients with Activity: Toxicity of Trisilioxane Surfactant Solutions to Twospotted Spider Mites (Acari: Tetranychidae). Journal of Economic Entomology 2000;93 180-188.

[165] Alix A, Cortesero AM, Nénon JP, Anger JP. 2001. Selectivity Assessment of Chlorfenvinphos Reevaluated by including Physiological and Behavioral Effects on an Important Beneficial Insect. Environmental Toxicology and Chemistry. 2001;20 25302536. 